\title{
Effect of daylength and food concentration on in situ diurnal feeding rhythms in Arctic copepods
}

\author{
E. J. H. Head ${ }^{1}$, L. R. Harris ${ }^{1}$ \& C. Abou Debs ${ }^{2}$ \\ ' Marine Ecology Laboratory, Bedford Institute of Oceanography, Department of Fisheries and Oceans, P.O. Box 1006, \\ Dartmouth, Nova Scotia B2Y 4A2, Canada \\ ${ }^{2}$ Institute des Sciences de la Nature, Université d'Annaba, Annaba, Algeria
}

\begin{abstract}
Zooplankton samples were collected from 0 to $50 \mathrm{~m}$ depth at 2 stations in Jones Sound and 1 in Baffin Bay in August and September of 1983. Levels of chlorophyll and phaeopigment were measured in several stages of Calanus hyperboreus and Calanus glacialis at $4 \mathrm{~h}$ intervals, to examine diurnal feeding behavior in copepods which do not vertically migrate on a daily basis. All stages examined for each of the 2 species showed diurnal variations in feeding activity. In addition, different stages and species always started to feed synchronously, although timing of onset of evening feeding was different at each of the 3 stations. On each occasion feeding started when incident light intensity decreased to $<4 \mathrm{~W} \mathrm{~m}^{-2}$. Cessation of feeding in the morning, however, was not linked to a particular intensity of incident light and may be controlled by satiation of appetite. Levels of 3 digestive enzymes - protease, laminarinase, and amylase - were measured in 2 stages of C. hyperboreus and C. glacialis at $4 \mathrm{~h}$ intervals over a $48 \mathrm{~h}$ time series at the second of the Jones Sound stations. There were no rhythmic changes in amounts of enzymes in any of the stages. Maximum levels of gut pigment within any 1 stage were not necessarily correlated with ambient chlorophyll concentrations, which varied by a factor of 4 among stations.
\end{abstract}

\section{INTRODUCTION}

Arctic regions are characterized by large changes in daylength throughout the year. At a latitude of $75^{\circ} \mathrm{N}$ there is $24 \mathrm{~h}$ sunlight from about mid-April to midAugust, after which daylength rapidly decreases, as does the intensity of noon-time illumination. The light cycle limits the period in which photosynthetic production is possible, and for the pelagic algal community, this is further restricted by ice cover in spring. In the eastern Canadian Arctic the abundant pelagic zooplankton community is dominated by the copepod herbivores Calanus hyperboreus and C. glacialis (Buchanan \& Sekerak 1982, Longhurst et al, 1984), which crowd into the surface layers to feed during the summer and then descend to overwinter at depths greater than $300 \mathrm{~m}$ (Dawson 1978, Kosobokova 1978, Longhurst et al. 1984). During this intense feeding period there is no significant diurnal migration in C. hyperboreus or C. glacialis (Båmstedt 1984, Longhurst et al. 1984), which contrasts with the behavior of $C$. finmarchicus when found in the Arctic (Sameoto 1984) and also in Calanus species in temperate regions (Bohrer
1980, Herman et al. 1981, Huntley \& Brooks 1982, Williams \& Conway 1984, Simard et al. 1985).

Differences in migratory behavior between that of the 2 Arctic Calanus species and that of other Calanus species suggested to us that their feeding behavior might also be different. C. finmarchicus in the Gulf of St. Lawrence feed predominantly at night (Simard et al. 1985) as do several other vertically migrating copepods from temperate regions (Mackas \& Bohrer 1976, Dagg \& Wyman 1983). For vertical migrators intermittent feeding is expected because they are only in contact with their food for part of the day. Nonmigrators, however, are in constant contact with their food, and this suggested that they might feed continuously; perhaps, in the Arctic, as an adaptation to a system where the potential annual feeding period is so short.

To test this hypothesis and the effects of ambient food concentration and daylength on feeding activity, we undertook 3 diurnal sampling series, 2 of $24 \mathrm{~h}$ and 1 of $48 \mathrm{~h}$ duration, in Jones Sound and Baffin Bay in August and September 1983 during a cruise on CSS Hudson. We examined levels of chlorophyll and 
phaeopigment in individual stages of Calanus hyperboreus and C. glacialis, as measures of feeding activity, and at 1 station, we measured levels of 3 digestive enzymes as indicators of digestive activity. We also measured chlorophyll concentrations and other indices of particulate organic matter and recorded incident light intensities throughout our sampling periods.

\section{MATERIALS AND METHODS}

Samples were collected with a 0.75 m diameter ring net of $800 \mu \mathrm{m}$ mesh in Jones Sound $\left(76^{\circ} \mathrm{N} 82^{\circ} \mathrm{W}\right)$ on August 18 and 19, in Baffin Bay $\left(72^{\circ} \mathrm{N} 68^{\circ} \mathrm{W}\right)$ on September 9 and 10 and in Jones Sound again on September 13 to 15 . These stations will be referred to as Stations 1,2 and 3 respectively. Vertical tows from $30 \mathrm{~m}$ were made at Station 1 and from $50 \mathrm{~m}$ at Stations 2 and 3 . Samples were collected every $4 \mathrm{~h}$ and processing times lasted no more than 30 min. After capture, zooplankton were immediately filtered onto sharkskin filter paper, frozen, and stored at $-20^{\circ} \mathrm{C}$ for subsequent analysis. In the laboratory, specimens of single stages of Calanus hyperboreus and C. glacialis ( 1 to 20 per stage) were sorted onto GFC filters. For gut pigment analysis, subsequent sample treatment and fluorescence measurement followed Mackas \& Bohrer (1976). Concentrations of chlorophyll and chlorophyll equivalent weight of phaeopigment were calculated according to Strickland \& Parsons (1972) and their sum was used as the index of gut fullness. Samples of individuais from Station 3 were also analysed for the levels of digestive protease, laminarinase, and amylase, after Head et al. (1984).
Particulate chlorophyll, protein and carbohydrate were measured as described by Head et al. (1984) after the methods of Yentsch \& Menzel (1963), Udenfriend et al. (1972) and Kotchert (1978), respectively. Particulate lipid was measured in duplicate on 250 or $500 \mathrm{ml}$ samples of seawater which had been filtered onto prebaked GFF filters, frozen and stored at $-20^{\circ} \mathrm{C}$. In the laboratory, filters were dried at room temperature in a vacuum desiccator over solid sodium hydroxide and extracted overnight at $\approx 1^{\circ} \mathrm{C}$, with a $2: 1(\mathrm{v}: \mathrm{v})$ chloroform : methanol mixture $(500 \mu \mathrm{l})$ in chloroform : methanol pre-washed glass vials. Extracts were then transferred through pre-washed cotton wool plugs into $2 \mathrm{ml}$ glass vials with conical bottoms. Filters and plugs were rinsed with the chloroform: methanol mixture $(2 \times 250 \mu \mathrm{l})$ and the combined extracts and washings were dried down, either by aspirating or by blowing with nitrogen. A few drops of chloroform $(\approx 200 \mu \mathrm{l})$ were then added to wash all of the material into the bottom of each vial and the samples were dried down by aspiration. Lipid was then determined using the sulphophosphovanillin reaction as described by Barnes \& Blackstock (1973). Values for particulate organic carbon (POC) were obtained either by $\mathrm{CHN}$ analysis (data courtesy of $\mathrm{B}$. Irwin) or by summing the POC values calculated from the analysis of particulate carbohydrate, protein and lipid, using conversion factors of $50 \% \mathrm{w} / \mathrm{w} \mathrm{C}, 50 \% \mathrm{w} / \mathrm{w} \mathrm{C}$ and $80 \% \mathrm{w} / \mathrm{w} \mathrm{C}$ for each of the 3 fractions respectively.

During diel studies, photosynthetically active incident light radiation ( 400 to $700 \mathrm{~nm}$ ) was continuously recorded over $1 \mathrm{~h}$ time intervals using a LICOR L190S Quantum Sensor and a L1550 Printing Integrator.

Table 1. Calanus hyperboreus and C. glacialis. Levels of gut pigment (ng ind ${ }^{-1}$ ) at Station 1. Values quoted with standard deviations, where appropriate. Numbers in brackets: numbers of sampled replicates (first number) and total numbers of animals in all replicates (second number)

\begin{tabular}{|c|c|c|c|c|c|c|c|}
\hline \multirow{2}{*}{$\begin{array}{c}\text { Jones Sound } \\
18 \text { and } 19 \text { Aug } \\
\text { Time }\end{array}$} & \multicolumn{4}{|c|}{ Calanus hyperboreus } & \multicolumn{3}{|c|}{ Calanus glacialis } \\
\hline & CVI F & $\mathrm{CV}$ & CIV & CIII & CVI F & $\mathrm{CV}$ & CIV \\
\hline 0930 & $\begin{array}{c}145.1 \\
(1,8)\end{array}$ & $\begin{array}{c}61.4 \\
(1,38)\end{array}$ & - & - & $\begin{array}{l}17.6 \\
(1,3)\end{array}$ & $\begin{array}{c}15.2 \pm 3.9 \\
(3,36)\end{array}$ & $\begin{array}{l}11.1 \\
(1,5)\end{array}$ \\
\hline 1400 & - & - & $\begin{array}{c}3.6 \\
(1,21)\end{array}$ & - & - & $\begin{array}{c}1.5 \\
(1,21)\end{array}$ & $\begin{array}{c}1.0 \pm 0.1 \\
(3,75)\end{array}$ \\
\hline 1830 & - & $\begin{array}{c}6.9 \\
(1,2)\end{array}$ & $\begin{array}{c}5.3 \pm 2.9 \\
(3,54)\end{array}$ & - & - & $\begin{array}{c}2.6 \\
(2,44)\end{array}$ & $\begin{array}{c}0.3 \pm 0.0 \\
(3,75)\end{array}$ \\
\hline 2200 & - & $\begin{array}{c}9.1 \\
(1,6)\end{array}$ & $\begin{array}{c}4.7 \pm 1.6 \\
(3.57)\end{array}$ & - & - & $\begin{array}{c}1.4 \pm 0.7 \\
(3.46)\end{array}$ & $\begin{array}{c}0.6 \pm 0.1 \\
(3.75)\end{array}$ \\
\hline 0130 & $\begin{array}{l}156.2 \\
(1,3)\end{array}$ & $\begin{array}{c}46.3 \\
(1,17)\end{array}$ & $\begin{array}{l}10.2 \\
(1,7)\end{array}$ & $\begin{array}{c}389 \\
(1,25)\end{array}$ & $\begin{array}{l}13.2 \\
(1,5)\end{array}$ & $\begin{array}{c}14.2 \pm 2.1 \\
(3,75)\end{array}$ & $\begin{array}{c}4.3 \\
(1,6)\end{array}$ \\
\hline 0500 & $\begin{array}{l}69.8 \\
(1,2)\end{array}$ & $\begin{array}{c}53.5 \pm 8.3 \\
(3,20)\end{array}$ & $\begin{array}{l}8.8 \\
(1,4)\end{array}$ & $\begin{array}{c}2.5 \pm 0.5 \\
(3,58)\end{array}$ & $\begin{array}{c}7.7 \\
(1,3)\end{array}$ & $\begin{array}{c}19.5 \pm 4.1 \\
(3,61)\end{array}$ & $\begin{array}{c}4.1 \\
(1,5)\end{array}$ \\
\hline
\end{tabular}


Table 2. Calanus hyperboreus and C. glacialis. Levels of gut pigment (ng ind ${ }^{-1}$ ) at Station 2. Values as for Table 1

\begin{tabular}{|c|c|c|c|c|c|c|}
\hline \multirow{2}{*}{$\begin{array}{c}\text { Baffin Bay } 9 \text { and } \\
10 \text { Sep } 1983 \\
\text { Time }\end{array}$} & \multicolumn{3}{|c|}{ Calanus hyperboreus } & \multicolumn{3}{|c|}{ Calanus glacialis } \\
\hline & $\mathrm{CV}$ & CIV & CIII & CVI F & $\mathrm{CV}$ & $\mathrm{CIV}$ \\
\hline 1200 & $\begin{array}{c}6.0 \\
(1,9)\end{array}$ & $\begin{array}{c}1.1 \pm 0.4 \\
(3,60)\end{array}$ & $\begin{array}{c}0.4 \pm 0.1 \\
(3,35)\end{array}$ & $\begin{array}{c}0.8 \\
(1,5)\end{array}$ & $\begin{array}{c}0.9 \\
(1,14)\end{array}$ & $\begin{array}{c}0.5 \pm 0.2 \\
(3,40)\end{array}$ \\
\hline 1620 & $\begin{array}{c}5.7 \\
(1.18)\end{array}$ & $\begin{array}{c}1.4 \pm 0.2 \\
(3,60)\end{array}$ & $\begin{array}{c}0.6 \pm 0.1 \\
(3,47)\end{array}$ & $\begin{array}{c}1.1 \\
(1,4)\end{array}$ & $\begin{array}{c}1.2 \\
(1,12)\end{array}$ & $\begin{array}{c}0.8 \pm 0.1 \\
(3,43)\end{array}$ \\
\hline 2000 & $\begin{array}{l}12.8 \\
(1,9)\end{array}$ & $\begin{array}{c}1.9 \pm 0.2 \\
(3,60)\end{array}$ & $\begin{array}{c}0.92 \\
(2,58)\end{array}$ & $\begin{array}{c}1.3 \\
(1,10)\end{array}$ & $\begin{array}{c}2.2 \\
(1.11)\end{array}$ & $\begin{array}{c}1.5 \\
(1,25)\end{array}$ \\
\hline 0050 & $\begin{array}{l}17.3 \\
(1.7)\end{array}$ & $\begin{array}{c}6.7 \pm 0.7 \\
(3,60)\end{array}$ & $\begin{array}{c}2.0 \pm 0.4 \\
(3,48)\end{array}$ & $\begin{array}{c}7.0 \\
(1.9)\end{array}$ & $\begin{array}{c}6.8 \\
(1,23)\end{array}$ & $\begin{array}{c}2.1 \pm 0.3 \\
(3,45)\end{array}$ \\
\hline 0345 & $\begin{array}{l}27.1 \\
(1,5)\end{array}$ & $\begin{array}{c}6.5 \pm 0.3 \\
(3,60)\end{array}$ & $\begin{array}{c}2.2 \\
(2,20)\end{array}$ & $\begin{array}{c}6.4 \\
(1,3)\end{array}$ & $\begin{array}{c}5.5 \\
(1.15)\end{array}$ & $\begin{array}{c}2.1 \\
(1,20)\end{array}$ \\
\hline 0745 & $\begin{array}{c}13.0 \\
(1,14)\end{array}$ & $\begin{array}{c}4.5 \\
(2,40)\end{array}$ & $\begin{array}{c}1.5 \\
(2,40)\end{array}$ & $\begin{array}{c}2.9 \\
(1,1)\end{array}$ & $\begin{array}{c}3.8 \\
(1.27)\end{array}$ & $\begin{array}{c}2.2 \\
(1,40)\end{array}$ \\
\hline
\end{tabular}

\section{RESULTS AND DISCUSSION}

Strong diurnal feeding rhythms were evident in every stage of Calanus hyperboreus and C. glacialis for which complete data sets were collected, at each of the 3 stations (Fig. 1, 2 \& 3; Table 1, 2 \& 3). Furthermore there was synchronization in the timing of onset of evening feeding in all of the stages and in both species, apparently even for incomplete data sets or for results obtained from only small numbers of individuals (Table 1, $2 \& 3$ ). Diurnal feeding rhythms were also observed by Peruyeva (1977) in Stage IV C. glacialis from the White Sea, although apparently not by Bămstedt (1984) for Stage V C. glacialis from Isfjord $\left(78^{\circ} \mathrm{N}\right)$ in early August. The apparent inconsistency is probably due to methodological differences. Båmstedt (1984) estimated the fraction of animals with empty guts in his samples, while Peruyeva (1978) and we ourselves determined the amount of food present in the gut. Båmstedt's method may have been inappropriate since these animals may not completely void their guts during the 'non-feeding' part of the day. For instance, while sampling we would observe green material in their guts at all times of the day.

In the Canadian Arctic, diurnal feeding rhythms are not related to vertical migratory behavior. Other authors have also found diurnal feeding patterns in non-migrating copepods (Boyd et al. 1980, Hayward 1980, Nicolajsen et al. 1983), but our results suggest a mechanism by which such feeding behavior might be controlled. Fig, 1, 2 and 3 show that the timing, with respect to solar midnight, of the onset of evening feeding is not constant at the 3 different stations. Instead, animals start to feed earlier in the evening as the season progress. At Station 1, feeding started $1 / 2$ to $4 \mathrm{~h}$ before solar midnight (between 2200 and $0130 \mathrm{~h}$ ). At Station 2 feeding seemed to start $5 \mathrm{~h}$ before solar midnight (between 1600 and $2000 \mathrm{~h}$ ) and at Station 3 animals began to feed some 6 to $8 \mathrm{~h}$ before solar midnight (between 1800 and $2200 \mathrm{~h}$ ). Comparison of these patterns of feeding activity with the diurnal light cycles
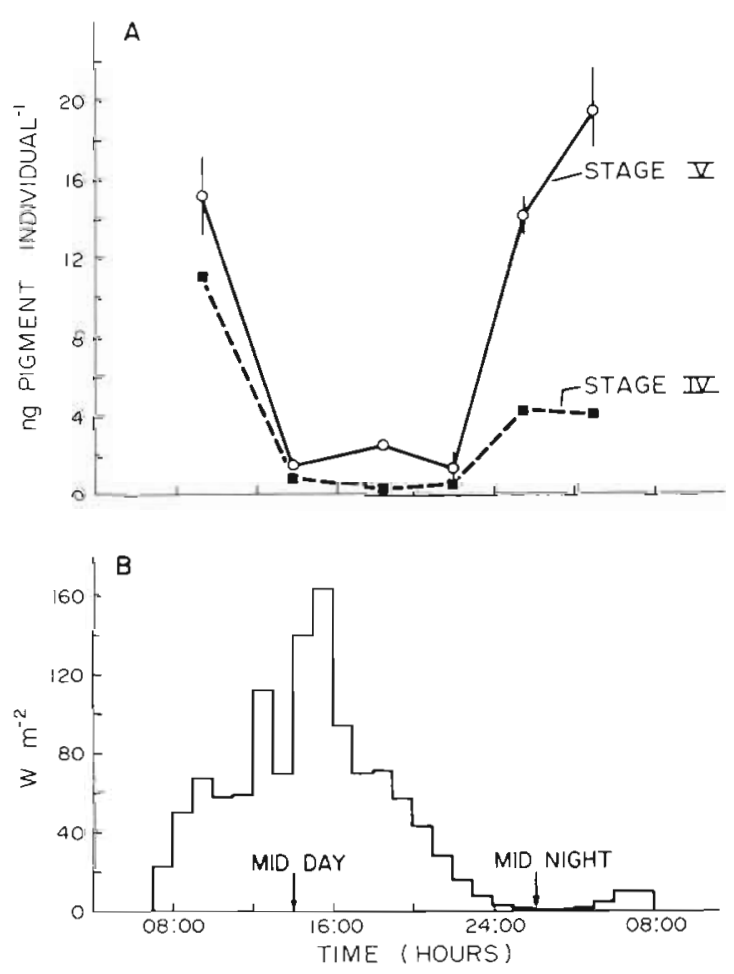

Fig. 1. Station 1, Jones Sound, Aug 18 and 19. (A) Calanus glacialis. Variations in total gut pigment levels in Stage Vs and Stage IVs. (B) Variation in level of incident light at the surface 

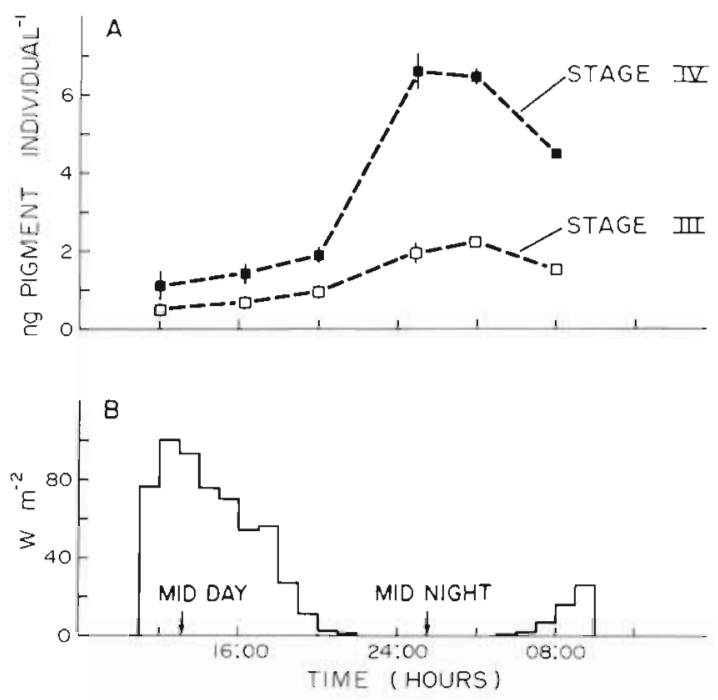

Fig. 2. Station 2, Baffin Bay, Sep 9 and 10. (A) Calanus hyperboreus. Variations in total gut pigment levels in State IVs and Stage IIIs. (B) Variation in level of incident light at the surface
(Fig. 1B, 2B \& 3C) show that feeding began after the incident light intensity had dropped below a certain 'critical' but undetermined level on each occasion. Hence, as well as controlling vertical migration, light may also have a direct and independent effect on feeding activitiy itself. Endogenous feeding rhythms have been observed in the laboratory, under conditions of continuous darkness (Duval \& Geen 1976), but in this in vivo situation these rhythms are modified in the presence of changing light cycles.

Fig. $4 \& 5$ show no rhythmic variations in levels of digestive enzymes, supporting the conclusion of Head et al. (1984) that levels of digestive enzymes are not indicative of instantaneous digestive rates. Usually variations in levels of enzymes were not more than $25 \%$ of the mean value for the whole sampling period, so that they were probably biologically insignificant anyway (Table 4). However, for Stage $V$ Calanus glacialis levels of all 3 enzymes were generally more variable. High variability among $C$. pacifus females has also been found in levels of some digestive enzy-
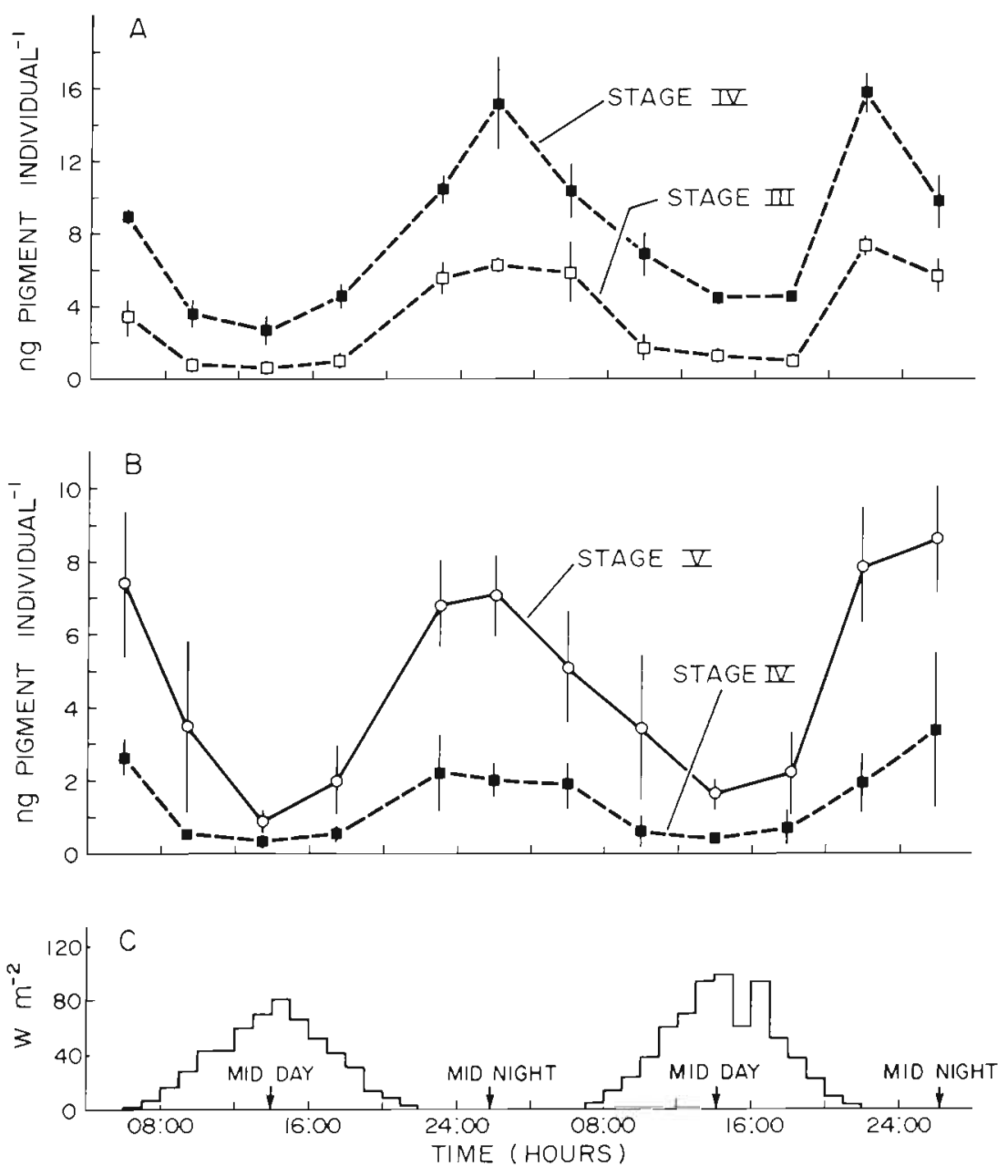

Fig. 3. Station 3, Jones Sound, Sep 13 and 15. (A) Calanus hyperboreus. Variations in total gut pigment levels in Stage IVs and Stage IIIs and (B) C. glacialis Stage Vs and Stage IVs. (C) Variation in level of incident light at the surface 
Table 3. Calanus hyperboreus and C. glacialis. Levels of gut pigment (ng ind ${ }^{-1}$ ) at Station 3. Values as for Table 1

\begin{tabular}{|c|c|c|c|c|c|c|}
\hline \multirow{2}{*}{$\begin{array}{c}\text { Jones Sound } \\
13 \text { to } 15 \text { Sep } \\
\text { Time }\end{array}$} & \multicolumn{4}{|c|}{ Calanus hyperboreus } & \multicolumn{2}{|c|}{ Calanus glacialis } \\
\hline & $\mathrm{CVIF}$ & $\mathrm{CV}$ & CIV & CIII & $\mathrm{CV}$ & CIV \\
\hline 0505 & - & $\begin{array}{c}27.1 \\
(1,6)\end{array}$ & $\begin{array}{c}8.8 \pm 0.4 \\
(3.53)\end{array}$ & $\begin{array}{c}3.4 \pm 1.1 \\
(3,41)\end{array}$ & $\begin{array}{c}7.4 \pm 2.1 \\
(1,34)\end{array}$ & $\begin{array}{c}2.6 \pm 0.6 \\
(3,48)\end{array}$ \\
\hline 0930 & - & $\begin{array}{c}14.6 \\
(1,6)\end{array}$ & $\begin{array}{c}3.5 \pm 0.8 \\
(3.60)\end{array}$ & $\begin{array}{c}0.7 \pm 0.1 \\
(3,60)\end{array}$ & $\begin{array}{c}3.5 \pm 2.4 \\
(3,42)\end{array}$ & $\begin{array}{c}0.5 \pm 0.1 \\
(3,60)\end{array}$ \\
\hline 1330 & $\begin{array}{l}46.4 \\
(1,2)\end{array}$ & $\begin{array}{c}13.9 \\
(1,7)\end{array}$ & $\begin{array}{l}2.7 \pm 0.9 \\
(3.49)\end{array}$ & $\begin{array}{c}0.6 \pm 0.3 \\
(3,53)\end{array}$ & $\begin{array}{c}0.9 \pm 0.2 \\
(3,38)\end{array}$ & $\begin{array}{c}0.3 \pm 0.1 \\
(3,38)\end{array}$ \\
\hline 1730 & $\begin{array}{l}32.3 \\
(1,2)\end{array}$ & $\begin{array}{c}30.0 \\
(1,9)\end{array}$ & $\begin{array}{c}4.5 \pm 0.7 \\
(3,60)\end{array}$ & $\begin{array}{c}1.0 \pm 0.2 \\
(3,60)\end{array}$ & $\begin{array}{c}2.0 \pm 0.9 \\
(3,33)\end{array}$ & $\begin{array}{c}0.5 \pm 0.1 \\
(3,45)\end{array}$ \\
\hline 2300 & $\begin{array}{l}13.6 \\
(1,1)\end{array}$ & $\begin{array}{c}28.4 \\
(1,5)\end{array}$ & $\begin{array}{c}10.4 \pm 0.9 \\
(3,60)\end{array}$ & $\begin{array}{c}5.5 \pm 0.9 \\
(3,60)\end{array}$ & $\begin{array}{c}6.9 \pm 1.2 \\
(3,60)\end{array}$ & $\begin{array}{c}2.2 \pm 1.0 \\
(3.60)\end{array}$ \\
\hline 0150 & $\begin{array}{r}148.7 \\
(1,4)\end{array}$ & $\begin{array}{l}45.4 \\
(1,8)\end{array}$ & $\begin{array}{c}15.1 \pm 2.5 \\
(3,60)\end{array}$ & $\begin{array}{c}6.2 \pm 0.2 \\
(3,60)\end{array}$ & $\begin{array}{c}7.1 \pm 1.4 \\
(3,60)\end{array}$ & $\begin{array}{c}2.0 \pm 0.5 \\
(3,60)\end{array}$ \\
\hline 0600 & $\begin{array}{r}110.7 \\
(1,1)\end{array}$ & $\begin{array}{c}20.6 \\
(1,6)\end{array}$ & $\begin{array}{c}10.3 \pm 1.5 \\
(3,60)\end{array}$ & $\begin{array}{c}5.8 \pm 1.7 \\
(3,60)\end{array}$ & $\begin{array}{c}5.1 \pm 1.6 \\
(3.60)\end{array}$ & $\begin{array}{c}1.9 \pm 0.6 \\
(3.55)\end{array}$ \\
\hline 0950 & $\begin{array}{l}57.0 \\
(1,3)\end{array}$ & $\begin{array}{c}27.2 \\
(1,6)\end{array}$ & $\begin{array}{l}6.8 \pm 1.2 \\
(3,60)\end{array}$ & $\begin{array}{c}1.7 \pm 0.7 \\
(3,60)\end{array}$ & $\begin{array}{c}3.5 \pm 1.9 \\
(3,57)\end{array}$ & $\begin{array}{c}0.7 \pm 0.4 \\
(3,60)\end{array}$ \\
\hline 1400 & $\begin{array}{l}33.7 \\
(1,5)\end{array}$ & $\begin{array}{l}22.0 \\
(1,2)\end{array}$ & $\begin{array}{c}4.4 \pm 2.0 \\
(3,60)\end{array}$ & $\begin{array}{c}1.2 \pm 0.1 \\
(3,60)\end{array}$ & $\begin{array}{c}1.7 \pm 0.3 \\
(3.52)\end{array}$ & $\begin{array}{c}0.5 \pm 0.0 \\
(3,60)\end{array}$ \\
\hline 1810 & $\begin{array}{l}31.2 \\
(1,3)\end{array}$ & $\begin{array}{c}17.9 \\
(1.14)\end{array}$ & $\begin{array}{c}4.5 \pm 0.2 \\
(3,60)\end{array}$ & $\begin{array}{c}0.9 \pm 0.2 \\
(3,60)\end{array}$ & $\begin{array}{c}2.3 \pm 1.2 \\
(3,38)\end{array}$ & $\begin{array}{c}0.8 \pm 0.5 \\
(3,50)\end{array}$ \\
\hline 2210 & $\begin{array}{l}55.3 \\
(1,4)\end{array}$ & $\begin{array}{c}26.6 \\
(1,17)\end{array}$ & $\begin{array}{c}15,7 \pm 1.1 \\
(3,60)\end{array}$ & $\begin{array}{c}7.3 \pm 0.3 \\
(3,60)\end{array}$ & $\begin{array}{c}7.9 \pm 1.7 \\
(3.41)\end{array}$ & $\begin{array}{c}2.0 \pm 0.8 \\
(3,56)\end{array}$ \\
\hline 0200 & $\begin{array}{l}60.1 \\
(1,5)\end{array}$ & $\begin{array}{c}27.1 \\
(1,14)\end{array}$ & $\begin{array}{c}9.7 \pm 1.5 \\
(3,60)\end{array}$ & $\begin{array}{c}5.7 \pm 0.9 \\
(3,60)\end{array}$ & $\begin{array}{c}8.7 \pm 1.7 \\
(3,28)\end{array}$ & $\begin{array}{c}3.4 \pm 2.2 \\
(3,15)\end{array}$ \\
\hline
\end{tabular}

Fig. 4. Calanus hyperboreus. Variation in levels of digestive enzymes in (A) Stage IVs and (B) Stage IIIs from Station 3. Results calculated from enzyme levels expressed on a per individual basis, and plotted as variations from mean value, calculated over whole sampling period, divided by their standard deviations from the mean. Solid circles: protease; open circles: laminarinase; open squares: amylase activities
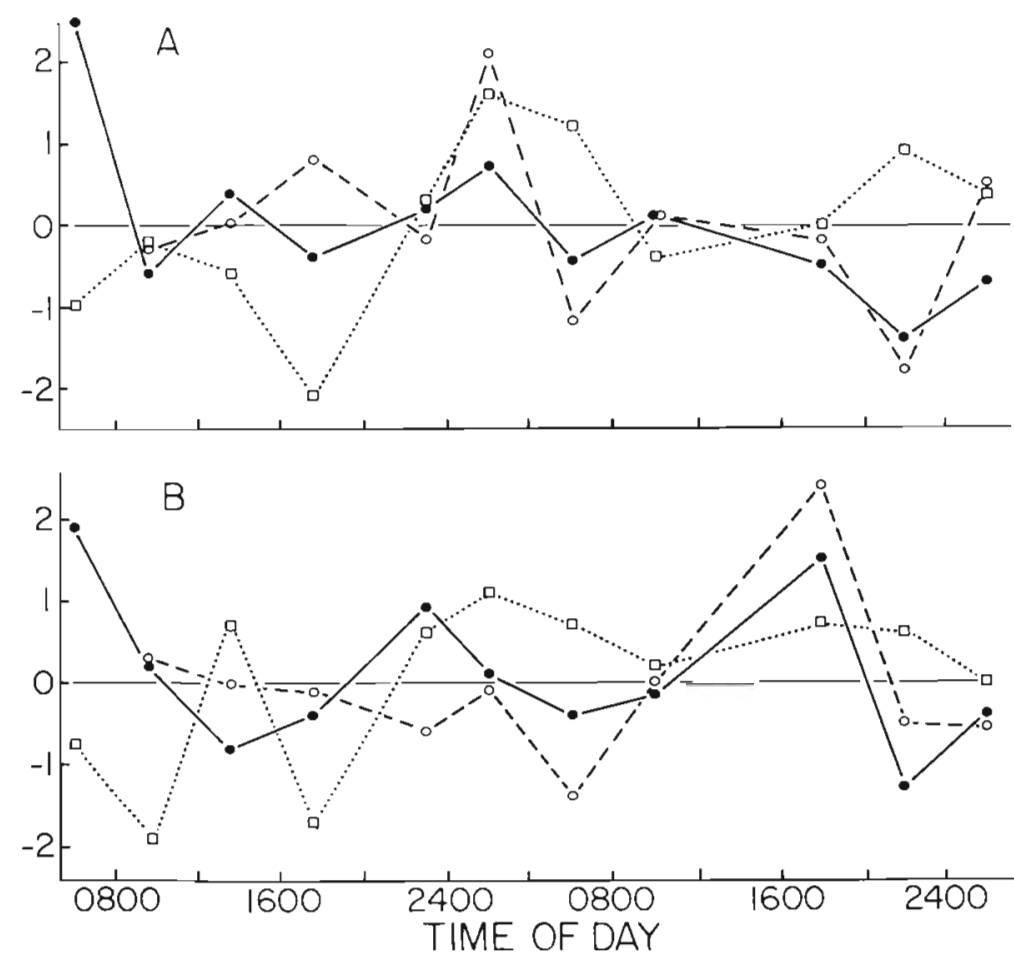

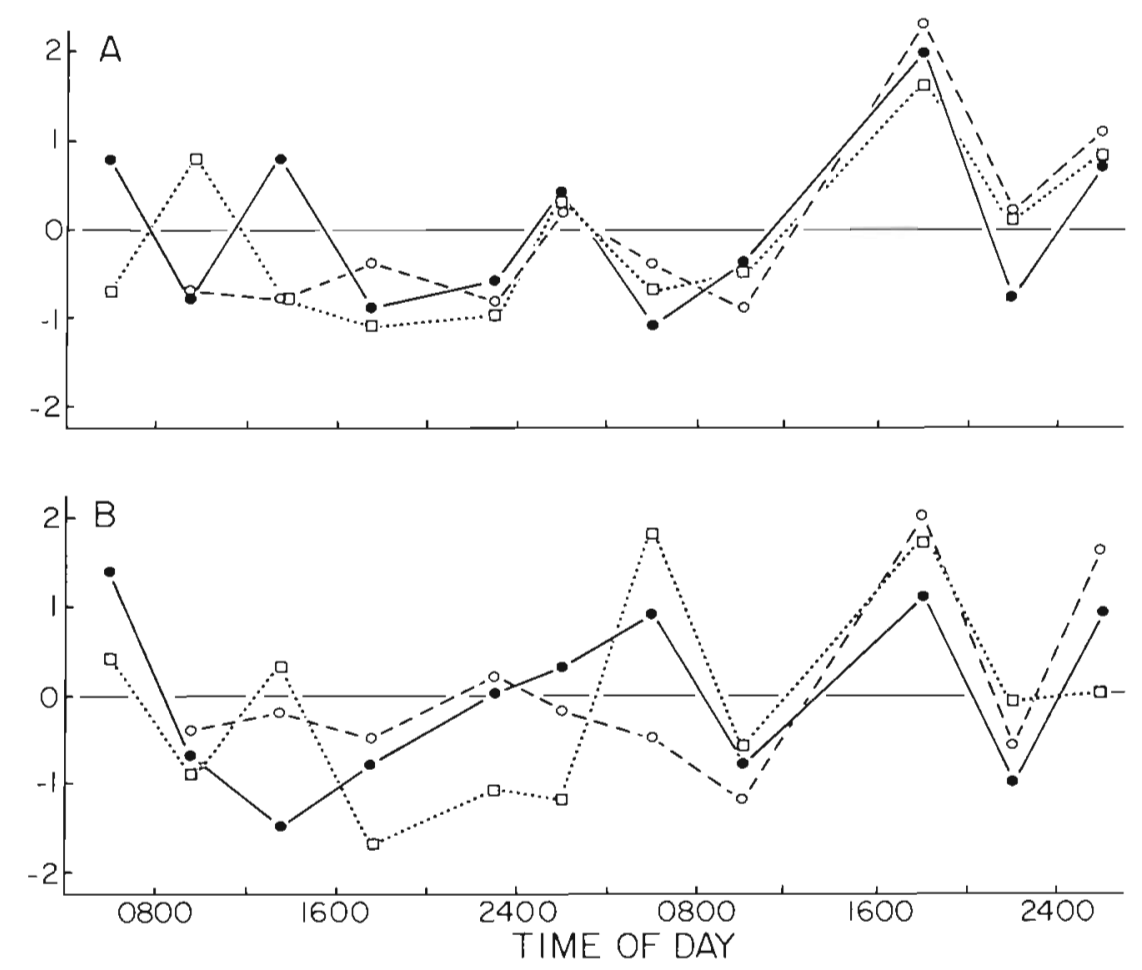

Fig. 5. Calanus glacialis. Variation in levels of digestive enzymes in (A) Stage Vs and (B) Stage IVs from Station 3. Results displayed as in Fig. 4

mes by Hassett \& Landry (1982). High variabilities have also been observed in soluble protein and lipid content in both female and Stage V C. hyperboreus and C. glacialis individuals from various eastern Canadian Arctic locations (Head \& Harris 1985, Head unpubl.) and it is likely that all these variabilities result from differences in the copepods' age, genetic background and/or feeding history.

Profiles of particulate chlorophyll to $100 \mathrm{~m}$ (Fig. 6) were very different at the 3 stations. Station 1 corresponded to an algal bloom, with a relatively shallow chlorophyll maximum at $10 \mathrm{~m}$. There was no nitrate detectable at the surface $\left(<0.1 \mu \mathrm{g}\right.$-at $\mathrm{N}^{-1}$ : B. Irwin pers. comm.), indicating that the bloom had probably

Table 4. Calanus hyperboreus and C. glacialis. Mean values and associated standard deviations of levels of digestive enzymes at 11 sampling times over a $48 \mathrm{~h}$ period at Station 3 . Each time point was for 2 replicate samples of 20 individuals and averages of enzyme levels at each time point were used to calculate mean values

\begin{tabular}{|c|c|c|c|}
\hline $\begin{array}{l}\text { Species } \\
\text { and stage }\end{array}$ & $\begin{array}{c}\text { Digestive } \\
\text { protease } \\
\mu \mathrm{gS} \mathrm{h}^{-1} \text { ind }^{-1}\end{array}$ & $\begin{array}{l}\text { Laminarinase } \\
\mu g S \mathrm{~h}^{-1} \text { ind }^{-1}\end{array}$ & $\begin{array}{c}\text { Amylase } \\
\mu \mathrm{gS} \mathrm{h}^{-1} \text { ind }^{-1}\end{array}$ \\
\hline \multicolumn{4}{|c|}{ Calanus hyperboreus } \\
\hline CIV & $51.3 \pm 5.3$ & $179.4 \pm 20.7$ & $51.3 \pm 4.9$ \\
\hline CIII & $24.4 \pm 3.6$ & $130.7 \pm 15.0$ & $22.5 \pm 4.6$ \\
\hline \multicolumn{4}{|c|}{ Calanus glacialis } \\
\hline $\mathrm{CV}$ & $47.1 \pm 8.1$ & $209.7 \pm 63.3$ & $103.6 \pm 25.1$ \\
\hline CIV & $21.8 \pm 2.7$ & $122.0 \pm 19.7$ & $49.0 \pm 6.5$ \\
\hline
\end{tabular}

passed its peak. At Station 2, in Baffin Bay, the chlorophyll maximum was at $25 \mathrm{~m}$, while at Station 3 chlorophyll was at a maximum at the surface, probably due to mixing in the upper $50 \mathrm{~m}$, perhaps caused by storm activity (E. Horne pers. comm.). Algal species compositions were also different at the chlorophyll maxima at the 3 stations, with a Thalassiosira sp. of 20 to $50 \mu \mathrm{m}$ diameter dominant at Station 1, coccolithophores of 3 to $10 \mu \mathrm{m}$ diameter dominant at Station 2 and a Chaetoceros sp. of 3 to $10 \mu \mathrm{m}$ diameter dominant at Station 3 (J. Trotte pers. comm.).

Maximum levels of gut pigment found in each stage at each station were not correlated with maximum concentrations of particulate chlorophyll in the water column (Table $5 \& 6$ ). Several other authors have also remarked on a lack of correlation between gut content and ambient food concentration (Hayward 1980, Dagg \& Wyman 1983, Wang \& Conover pers. comm.), although Kiorboe et al. (1982) found a non-linear increase in gut pigment level with food concentration in experiments with Centropages hamatus fed Ditylum brightwelli. They used a relationship of the form

$$
\mathrm{S}=\mathrm{S}_{\max } \mathrm{e}^{\left(-\beta^{\prime} / C\right)}
$$

to describe their results, where $\mathrm{S}=$ gut pigment content; $\beta^{\prime}=$ a constant; $C=$ food concentration measured in terms of particulate chlorophyll concentration. Such a relationship only holds for a given food source, however, because $S_{\max }$ will vary with the chlorophyll content of the food, and $\beta^{\prime}$ might be expected to vary with its acceptability as a food source. These considerations 
mean that maximum gut pigment levels for copepods feeding on different food sources may not be good indicators of either gut fullness or feeding activity. In our data the particulate material at the chlorophyll maximum at Stations 1 and 3 had similar carbon: chlorophyll ratios (Table 6), which may account for the similarity of gut pigment levels in some of the stages from these 2 stations if $\beta^{\prime} / C$ was very small in either case, so that $S \approx S_{\max }$. At the second station the algal species composition was very different from that at the other two. The carbon: chlorophyll ratio of the particulate material was apparently also very different (Table 6), but this might reflect either the presence of non-algal carbon or may be due to errors introduced by calculating POC values from chemical analyses. Thus differences in $\beta^{\prime}$ and $S_{\max }$ may both have contributed to the observed differences in maximum gut pigment levels in specimens at this station. It should be emphasized also that none of these static measurements allow us to make statements about relative feeding rates between the different stations.

Regardless of differences in food composition and concentration, the consistent patterns of diurnal feeding activity are striking and raise the question as to what might be the adaptive significance of such behavior. Among the reasons invoked for vertical migration are avoidance of visual predation (Zaret \& Suffern 1976), and an energetic argument whereby animals decrease their metabolic rates during the day by swimming down through the thermocline to water of lower temperature after feeding in warmer nearsurface waters (McLaren 1963). In Resolute $\left(75^{\circ} \mathrm{N}\right)$ the noon-time maximal July-August incident light intensity is similar to February noon-time in Nova Scotia $\left(45^{\circ} \mathrm{N}\right)$, so that low sub-surface light levels even in high summer may make visual predation inefficient, thus removing one of the ecological advantages of vertical migration. In addition, the temperature difference above and below the thermocline is usually only about $2 \mathrm{C}^{\circ}$, so that the energetic argument also becomes redundant. Hence the observed lack of vertical migration in Arcitc copepods might result from the lack of appropriate environmental stimuli. An alternative hypothesis might be that separate genes exist for vertical migration and diurnal feeding in copepods

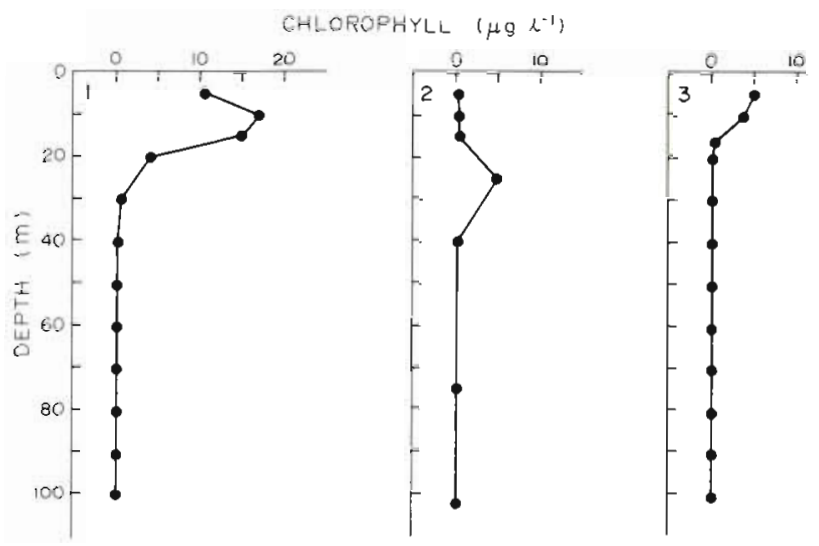

Fig. 6. Chlorophyll profiles to $100 \mathrm{~m}$ at Stations 1, 2 and 3

and that these are usually expressed together. Arctic copepods, however, might have lost the migratory gene while retaining the gene for discontinuous feeding. The latter hypothesis is suggested on the basis of results of Sameoto (1984), who observed that Calanus finmarchicus, a known vertical migrator, did migrate in north Baffin Bay at a location where neither $C$. hyperboreus nor C. glacialis did. These findings also suggest that the vertical migratory behavior is more probably a response to light than to temperature conditions. McAllister (1970) suggested that diel feeding could benefit both phytoplankton and zooplankton if the zooplankton concentrate their feeding times early in the evening where they utilize the maximal amount

Table 5. Calanus hyperboreus and C. glacialis. Maximum levels of gut pigment recorded in each of the sampling series for the sampled stages

\begin{tabular}{|c|c|c|c|}
\hline \multirow[t]{2}{*}{$\begin{array}{l}\text { Species and } \\
\text { stage }\end{array}$} & \multicolumn{3}{|c|}{$\begin{array}{c}\text { Maximum gut pigment levels } \\
\text { (ng ind } \mathrm{d}^{-1} \text { ) }\end{array}$} \\
\hline & $\operatorname{Stn} 1$ & $\operatorname{Stn} 2$ & $\operatorname{Stn} 3$ \\
\hline \multicolumn{4}{|c|}{ Calanus hyperboreus } \\
\hline CVIF & 156 & - & 150 \\
\hline $\mathrm{CV}$ & 60 & 27 & 40 \\
\hline CIV & 11 & 7 & 15 \\
\hline $\mathrm{CIII}$ & 4 & 2 & 7 \\
\hline \multicolumn{4}{|l|}{ Calanus glacialis } \\
\hline CVIF & 13 & 7 & - \\
\hline $\mathrm{CV}$ & 20 & 7 & 7 \\
\hline CIV & 4 & 2 & 3 \\
\hline
\end{tabular}

Table 6. Levels of particulate chlorophyll and particulate organic carbon (POC), and ratio of POC: chlorophyll, at the chlorophyll maximum depths $(10,25$ and $5 \mathrm{~m})$ at each sampling station

\begin{tabular}{|lcrrr|}
\hline Sampling area (Date) & $\begin{array}{c}\text { Chlorophyll } \\
\left(\mu \mathrm{g} \mathrm{l}^{-1}\right)\end{array}$ & $\begin{array}{c}\text { POC }\left(\mu \mathrm{g} \mathrm{l}^{-1}\right) \text { from } \\
\text { CHN analysis }\end{array}$ & $\begin{array}{c}\text { PoC }\left(\mu \mathrm{l}^{-1}\right) \text { from } \\
\text { chemical analysis }\end{array}$ & $\begin{array}{c}\text { POC: } \\
\text { chlorophyll }\end{array}$ \\
\hline Jones Sound (18 and 19 Aug 1983) & 17 & 1171 & 1063 & 66 \\
Baffin Bay (9 and 10 Sep 1983) & 5 & - & - & 145 \\
Jones Sound (13 to 15 Sep 1983) & 5 & 281 & 56 \\
\hline
\end{tabular}


of photosynthetically fixed energy before appreciable phytoplankton respiration has occurred. Platt et al. (1982) found that the compensation light intensity for near-surface Arctic phytoplankton was $1.3 \mathrm{~W} \mathrm{~m}^{-2}$. Hence our observations that feeding did not start until surface light intensities had dropped below about $4 \mathrm{~W} \mathrm{~m}^{-2}$ at each station support McAllister's ideas. Previous tests of the hypothesis have involved arguments concerning the timing of vertical migration, supposedly associated with nocturnal feeding behavior (Enright \& Honegger 1977). We, however, suggest that vertical migration and diurnal feeding activity are controlled independently, although probably both mediated by light. Future studies should not therefore assume co-incidence of the 2 behavior patterns but should in fact seek to further elucidate them independently.

Acknowledgements. The authors thank Dr. R. J. Conover for helpful criticism in the preparation of this manuscript.

\section{LITERATURE CITED}

Båmstedt, U. (1984). Diel variations in the nutritional physiology of Calanus glacialis from Lat. $78^{\circ} \mathrm{N}$ in the summer. Mar. Biol. 79: 257-267

Barnes, H., Blackstock, J. (1973). Estimation of lipids in marine animals and tissues: detailed investigation of the sulphophosphovanillin method for 'total' lipids. J. exp. mar. Biol. Ecol. 12: 103-118

Bohrer, R. N. (1980). Experimental studies on diel vertical migration. In: Kerfoot, W. C. (ed.) Evolution and ecology of zooplankton. University Press of New England, Hanover, New Hampshire, p. 111-121

Boyd, C. M., Smith, S. L., Dowles, T. J. (1980). Grazing patterns of copepods in the upwelling system off Peru. Limnol. Oceanogr. 25: 583-596

Buchanan, R. A., Sekerak, A. D. (1982). Vertical distribution of zooplankton in Eastern Lancaster Sound and Western Baffin Bay Canada July-Oct. 1978. Arctic 35: 41-55

Dagg, M. J., Wyman, K. D. (1983). Natural ingestion rates of the copepods Neocalanus plumchrus and N. cristatus calculated from gut contents. Mar. Ecol. Prog. Ser. 13: 37-46

Dawson, J. K. (1978). Vertical distribution of Calanus hyperboreus in the central Arctic Ocean. Limnol. Oceanogr. 23: 950-957

Duval, W. S., Geen, G. H. (1976). Diel feeding and respiration rhythms in zooplankton. Limnol. Oceanogr. 21: 823-829

Enright, J. T., Honegger, H. W. (1977). Diurnal vertical migration: Adaptive significance and timing. Part 2. Test of the model: Details of timing. Limnol. Oceanogr. 22: 873-886

Hassett, R. P., Landry, M. R. (1982). Digestive carbohydrase activities in individual marine copepods. Mar. Biol. Lett. 3: $211-221$

Hayward, T L. (1980). Spatial and temporal feeding patterns of copepods from the North Pacific Central Gyre. Mar. Biol. 58: 295-309

Head, E. J. H., Harris, L. R. (1985). Physiological and biochemical changes in Calanus hyperboreus from Jones Sound NWT during the transition from summer feeding to overwintering condition. Polar Biol. 4: 99-106

Head, E. J. H., Wang, R., Conover, R. J. (1984). Comparison of diurnal feeding rhythms in Temora longicornus and Centropages hamatus with digestive enzyme activity. J. Plankton Res. 6: 543-551
Herman, A. W., Sameoto, D. D., Longhurst, A. R. (1981). Vertical and horizontal distribution patterns of copepods near the shelf break south of Nova Scotia. Can. J. Fish. aquat. Sci. 38: 1065-1076

Huntley, M., Brooks, E. R. (1982). Effects of age and food availability on diel vertical migration of Calanus pacificus. Mar. Biol. 71: 23-31

Kiorboe, T., Mohlenberg, F., Nicolajsen, H. (1982). Ingestion rate and gut clearance in the planktonic copepod Centropages hamatus (Lilljeborg) in relation to food concentration and temperature. Ophelia 21: 181-194

Kosobokova, K. N. (1978). Diurnal vertical distribution of Calanus hyperboreus Kroyer and Calanus glacialis Jaschnov in the central Polar Basin. Oceanology 18: 476-480

Kotchert, G. (1978). Carbohydrate determination by the phenol-sulfuric acid method. In: Hellebust, J. A., Craigie, J. S. (ed.) Handbook of phycological methods - physiological and biochemical methods. Cambridge Univ. Press, Cambridge, p. 95-97

Longhurst, A., Sameoto, D., Herman, A. (1984). Vertical distribution of Arctic zooplankton in summer: eastern Canadian archipelago. J. Plankton Res. 6: 137-168

Mackas, D. L., Bohrer, R. (1976). Fluorescence analysis of zooplankton gut contents and investigation of diel feeding patterns. J. exp. mar. Biol. Ecol. 25: 77-85

McAllister, C. D. (1970). Zooplankton rations, phytoplankton mortality and the estimation of marine production. In: Steele, J. H. (ed.) Marine food chains. Oliver and Boyd, Edinburgh, p. 419-457

McLaren, T. A. (1963). Effects of temperatures on growth of zooplankton and the adaptive value of vertical migration. J. Fish. Res. Bd Can. 20: 685-727

Nicolajsen, H., Molenberg, F., Kiorboe, T. (1983). Algal grazing by the planktonic copepods Centropages hamatus and Pseudocalanus sp. Diurnal and seasonal variation during the spring phytoplankton bloom in the Oresund. Ophelia 22: $15-31$

Peruyeva, Ye. G. (1977). Diumal feeding rhythm of IV copepodite stage of Calanus glacialis Jaschnov. Oceanology 17: 719-721

Platt, T., Harrison, W. G., Irwin, B., Horne, E. P., Gallegos, C. L. (1982). Photosynthesis and photoadaptation of marine phytoplankton in the Arctic. Deep Sea Res. 29: 1159-1170

Sameoto, D. D. (1984). Vertical distribution of zooplankton biomass and species in northeastern Baffin Bay related to temperature and salinity. Polar Biol. 2: 213-224

Simard, Y., Lacroix, G., Legendre, L. (1984). In situ twilight grazing rhythm during diel vertical migrations of a scattering layer of Calanus finmarchicus. Limnol. Oceanogr. 30: $598-606$

Strickland, J. D. H., Parsons, T. R. (1972). A practical handbook of seawater analysis. 2nd edition. Bull. Fish. Res. Bd Can. 167

Udenfriend, S., Stein, S., Bohlen, P., Dairman, W., Leimgruber, W., Wiegele, M. (1972). Fluorescamine: a reagent for assay of amino acids, peptides, proteins and primary amines in the picomole range. Science 17:871-872

Williams, R., Conway, D. V. P. (1984). Vertical distribution and seasonal and diurnal migration of Calanus helgolandicus in the Celtic Sea. Mar. Biol. 79: 63-73

Yentsch, C. S., Menzel, D. W. (1963). A method for the determination of phytoplankton chlorophyll and phaeophytin by fluorescences. Deep Sea Res. 10: 221-231

Zaret, T. M., Suffern, J. S. (1976). Vertical migration as a predator avoidance mechanism. Limnol. Oceanogr. 21 804-813 